\title{
Evaluation of Replacing Natural Gas Heat Plant with a Biomass Heat Plant - A Technical Review of Greenhouse Gas Emission Trade-Offs
}

\author{
James G. Droppo and Xiao-Ying Yu \\ Pacific Northwest National Laboratory
}

USA

\section{Introduction}

Proposed fuel conversions can involve more than a simple reduction of emission rates. For example, a Renewable Fuel Heating Plant (RFHP) was proposed for the U.S. Department of Energy (DOE) National Renewable Energy Laboratory (NREL) to replace a natural gas plant. The proposed RFHP replacement plant was to use a biomass fuel, wood chips. A review was conducted to address questions related to how increases in the plant's carbon dioxide $\left(\mathrm{CO}_{2}\right)$ emission rates could represent a desirable outcome. This review and its results are published here in the hope that it may be useful to others considering similar conversions. This chapter addresses 1) why despite an increase in emission rate the conversion is considered an effective reduction in greenhouse gas emissions, and 2) how the proposed wood chip combustion process emissions compare with other means of disposing of or using wood chips.

The 2001 and 2007 Assessment Reports of the Intergovernmental Panel on Climate Change (IPCC) considers the evidence for global climate change and the potential consequences of such changes [IPCC, 2001; 2007]. Based on the result of worldwide research efforts, this paper concludes that the earth's climate has changed over the last century. It also notes that there is recent strong evidence that human activities have caused most of the warming observed in the last 50 years. The current computer models are predicting that this temperature rise should continue over this century.

In terms of the net $\mathrm{CO}_{2}$ in the atmosphere, the argument is made based on current scientific understanding on climate change processes, that burning of wood chips is much more desirable than a fuel that contains carbon that has been sequestered underground. The $\mathrm{CO}_{2}$ from wood chip combustion has a "net zero" emission rate based on factors in the Environmental Protection Agency's AP-42. The "net zero" emission rate is based on an assumption that $\mathrm{CO}_{2}$ from burning wood from forests represents no increase in the net amount of $\mathrm{CO}_{2}$. A cycling of carbon between the atmosphere and forests results in no net gain or loss of airborne $\mathrm{CO}_{2}$. On the other hand $\mathrm{CO}_{2}$ from burning natural gas represents an increase in the net amount of $\mathrm{CO}_{2}$ from the introduction of "new" carbon that has been previously sequestered underground. Thus argument for the proposed conversion is to stop the introduction of the new carbon into the current atmospheric carbon cycle. 
From the viewpoint of minimizing impacts on global climate change, the burning of wood chips also tends to be more desirable than the common alterative use of wood chips in composting activities. Although there is great variability and uncertainty in the published emission rates, the gaseous emission from both open burning and composting tend to have much larger emissions of greenhouse gases, and specifically larger fractions of gases such as methane $\left(\mathrm{CH}_{4}\right)$ and ammonia $\left(\mathrm{NH}_{3}\right)$ than the proposed process for burning the wood chips. The published source terms for open burning show the incineration option to be preferable from the viewpoint of having lower emissions. Of particular importance are mixtures of combustion products from these activities. For example because methane is currently thought to be many times more effective for inducing climate changes than $\mathrm{CO}_{2}$, the potentially higher methane levels from open burning and composting make these activities less desirable from the viewpoint of minimizing the potential impact of greenhouse gas emissions.

The paradox in the proposed conversion is that from an absolute quantity perspective the RFHP would emit more $\mathrm{CO}_{2}$ than what is being currently emitted with natural gas firing. Although the main thrust in reducing atmospheric levels of greenhouse gases has been to reduce introduction of "new" carbon by the combustion of fossil fuels, some efforts have considered the possibility of combustion control strategies for agricultural and forestry products.

A review was conducted of recent literature relevant to these issues. The predominance of current literature points to a need to reduce greenhouse emissions, and it is assumed for the purpose of this review to be a reasonable basis for proceeding with actions that will reduce those emissions. The results of this review are reported below. A form of these results were posted as a DOE report, we would like to make it avaiable in the public domain for people who are interested in this topic.

\section{Background}

The Third and Fourth Assessment Reports of the IPCC [2001, 2007] considers the evidence for global climate change and the potential consequences of such changes ${ }^{1}$. Based on the result of worldwide research efforts, the report concludes that the earth's climate has changed over the last century. These reports also notes that there is mounting evidence that human activities have caused most of the warming observed in the past 50 years. The current computer models predict that this temperature rise should continue over this century.

The IPCC reports note that changes in climate are the result of both internal variability within the climate system and external factors (both natural and anthropogenic). Human emissions are significantly modifying the concentrations of some gases in the atmosphere. Some of these gases are expected to affect the climate by changing the earth's radiative balance, measured in terms of radiative forcing.

The 2007 IPCC reports provide an overview of the global effects of greenhouse gases and conclude that they tend to warm the earth surface by absorbing some of the infrared radiation it emits.

${ }^{1}$ The reader is referred to the websites http://www.ipcc.ch/ and "http://www.greenfacts.org" for additional information. The latter site provides summaries as well as quotes from the IPCC (2007) report. 
"The principal anthropogenic greenhouse gas is carbon dioxide $\left(\mathrm{CO}_{2}\right)$, whose concentration has increased by $31 \%$ since 1750 to a level which is likely to have not been exceeded for 20 million years. This increase is predominantly due to fossil fuel burning, but also to land-use change, especially deforestation. The other significant anthropogenic greenhouse gases are $\mathrm{CH}_{4}\left(151 \%\right.$ increase since 1750, 1/3 of $\mathrm{CO}_{2}$ 's radiative forcing), halocarbons such as CFCs and their substitutes $(100 \%$ anthropogenic, $1 / 4$ of $\mathrm{CO}_{2}$ 's radiative forcing) and nitrous oxide $\left(\mathrm{N}_{2} \mathrm{O}\right)(17 \%$ increase since $1750,1 / 10$ of $\mathrm{CO}_{2}$ 's radiative forcing)."

The IPCC [2007] attributes that about three-quarters of the anthropogenic emissions of $\mathrm{CO}_{2}$ to the atmosphere during the past 20 years is due to fossil fuel burning. The rest is attributed to predominantly land-use change, especially deforestation.

"Currently the ocean and the land together are seen as taking up about half of the anthropogenic $\mathrm{CO}_{2}$ emissions. On land, the uptake of anthropogenic $\mathrm{CO}_{2}$ is thought to very likely exceed the release of $\mathrm{CO}_{2}$ by deforestation during the 1990s. The rate of increase of atmospheric $\mathrm{CO}_{2}$ concentration has been about $1.5 \mathrm{ppm}(0.4 \%)$ per year over the past two decades. During the 1990s the year to year increase varied from $0.9 \mathrm{ppm}$ $(0.2 \%)$ to $2.8 \mathrm{ppm}(0.8 \%)$. A large part of this variability is due to the effect of climate variability (e.g., El Niño events) on $\mathrm{CO}_{2}$ uptake and release by land and oceans."

Studies of the signatures of emissions from biomass and fossil fuel burning conducted by Reiner et al. [2001] over the tropical Indian Ocean provides some insight into the relative source importance. In the air from the continent they found that most of the $\mathrm{CO}$ is from biomass/biofuels burning and the majority of the aerosols are from fossil fuel burning. These results underscore the apparent importance of incomplete combustion products in the current emissions from combustion of biomass/biofuels.

The literature indicates that there is a world-wide effort to define means and methods of using bio-energy while minimizing greenhouse gas emissions. Faaij [2006] states that bioenergy is one of the key options to mitigate greenhouse gas emissions and substitute fossil fuels. The efforts are reflected in the wide range of activities and programs for developing and stimulating bio-energy.

\section{Emission rates}

This review focuses on greenhouse gas emissions from a proposed wood fired boiler and their existing natural gas boiler and from other alternative uses of the wood chips. The current and proposed emissions rates as well as the assumed annual tonnage of wood consumed are provided by DOE/NREL. A literature search was conducted with the objective of quantifying annual air emissions that would result from the likely alternative uses of the wood proposed to be used by PRFHP. The three alternatives considered were composting, land filling and open burning. Because each of these alternatives represents a wide range of processes, it is expected that there will be correspondingly a wide range of potential emissions from each of these alternatives.

As a result of a worldwide concern over the potential effect of greenhouse gases, the current literature contains considerable information on the potential emissions. These papers include process-specific studies of the emissions from biomass burning and other biofuel combustion processes (i.e. Borgwardt, 1997; Turn et al., 1997; Dennis et al., 2002; Hays 
et al.2, 2002; Kasische and Penner, 2004; Hayes et al., 2005; Pronobis, 2006; Hashaikeh et al., 2007; Tilman et al., 2007] as well as quantification of global emissions from conventional and biogenic processes (i.e. Oros and Simonett, 2001; Ito and Penner, 2004; Liebig, 2005; Wiedinmyer et al., 20063; Schmid et al., 20064; Khalil et al.,20075). The attached list of citations for papers considered in this review contains additional references concerning both process and global emission rates.

The emphasis of this review is to compare the emissions from natural gas and the wood fired boiler with comparable emission numbers for the same annual volume of wood disposed of by the alternative means. Specifically the comparison is based on the wood is either 1) processed into compost; 2) dumped in a landfill; or 3) subjected to open burning à la the forest service's preferred method for slash pile disposal.

Winiwarter [2001] detailed evaluation shows that "much of the overall uncertainty derives from a lack of understanding of the processes associated with $\mathrm{N}_{2} \mathrm{O}$ emissions from soils. Other important contributors to greenhouse gas emission uncertainties are $\mathrm{CH}_{4}$ from landfills and forests as $\mathrm{CO}_{2}$ sinks. The uncertainty of the trend has been determined at near $5 \%$ points, with solid waste production (landfills) having the strongest contribution."

\subsection{Proposed heat plant emissions}

Table 1 shows a comparison of the emissions from the current natural gas and proposed biomass heat plants. Annual emissions from the proposed heat plant are based on a permitted 3,800 tons of biomass, at approximately 6,500 Btu/lb heating value. This maximum annual fuel consumption is based on the assumption that biomass has thirty to forty percent moisture. Uncontrolled emissions are based on emission factors referenced in the United States Environmental Protection Agency's (U.S. EPA's) AP-42 Compilation of Air Pollutant Emission Factors (5th edition), Chapter 1.6 Wood Residue Combustion in Boilers.

\begin{tabular}{|c|c|c|}
\hline Combustion Scenario & Current Heat Plant & Woodchip Heat Plant \\
\hline Air Pollutant & $\begin{array}{c}\text { Existing Emissions using } \\
\text { Natural Gas Boilders }\end{array}$ & Wood Combustion \\
\hline Units & tons/yr & tons/yr \\
\hline Carbon Monoxide $(\mathrm{CO})$ & 1.69 & 3.58 \\
\hline Sulfur Dioxide $\left(\mathrm{SO}_{2}\right)$ & 0.012 & 0.5 \\
\hline Nitrogen Oxide $\left(\mathrm{NO}_{\mathbf{x}}\right)$ & 3.3 & 4.3 \\
\hline PM Total & 0.1 & 3.2 \\
\hline VOC (non methane) & 0.1 & 0.1 \\
\hline Carbon Dioxide $\left(\mathrm{CO}_{2}\right)$ & 2340 & Net zero \\
\hline
\end{tabular}

Table 1. Emissions Comparison of Current Natural Gas and Proposed Biomass Heat Plants

2 Considers emissions from burning of several types of wood.

${ }^{3}$ Estimation of emissions from fires in North America.

${ }^{4}$ Considers carbon budget for forests.

${ }^{5}$ Recent summary of importance of atmospheric methane as a greenhouse gas. 


\subsubsection{Composting}

For all compositing activities, the products produced depend heavily on conditions. High (i.e. greater than $50 \%$ ) moisture content is a prerequisite for having high levels of microbial activities [Lang et al., 2006]. Dispite the wide range of possible emissions; it is possible to describe general trends from composting.

The aerobic composting of chips from clear-cut trees is considered by Suzuk et al. [2004]. They found that certain combinations of materials could be composed within 10 months time period. Although they did not specifically consider the emissions, it is likely that emissions of $\mathrm{CO}_{2}$ and $\mathrm{CH}_{4}$ are much lower than what would have occurred with anaerobic composting.

IPCC (2007) states that:

"Composting refers to the aerobic digestion of organic waste. The decomposed residue, if free from contaminants, can be used as a soil conditioner. As noted above under landfilling, greenhouse gas emissions from composting are comparable to landfilling for yard waste, and lower than landfilling for food waste. These estimates do not include the benefits of the reduced need for synthetic fertilizer, which is associated with large $\mathrm{CO}_{2}$ emissions during manufacture and transport, and $\mathrm{N}_{2} \mathrm{O}$ releases during use. USDA research indicates that compost usage can reduce fertilizer requirements by at least 20\% [Ligon, 1999], thereby significantly reducing net greenhouse gas emissions.

Composting of yard waste has become widespread in many developed countries, and some communities compost food waste as well. Small, low-technology facilities handling only yard waste are inexpensive and generally problem-free. Some European and North American cities have encountered difficulties implementing large-scale, mixed domestic, commercial and industrial bio-waste collection and composting schemes. The problems range from odor complaints to heavy metal contamination of the decomposed residue. Also, large-scale composting requires mechanical aeration which can be energy intensive (40-70 kW/ $\mathrm{t}$ of waste) [Faaij et al., 1998]. However, facilities that combine anaerobic and aerobic digestion are able to provide this energy from self-supplied methane. If $25 \%$ or more of the waste is digested anaerobically the system can be self-sufficient [Edelmann and Schleiss, 1999].

For developing countries, the low cost and simplicity of composting, and the high organic content of the waste stream make small-scale composting a promising solution. Increased composting of municipal waste can reduce waste management costs and emissions, while creating employment and other public health benefits.

Anaerobic digestion to produce methane for fuel has been successful on a variety of scales in developed and developing countries. The rural biogas programmes based upon manure and agricultural waste in India and China are very extensive. In industrial countries, digestion at large facilities utilizes raw materials including organic waste from agriculture, sewage sludge, kitchens, slaughterhouses, and food processing industries. “

\subsubsection{Landfill}

Disposal of wood chips in a landfill can result in a wide range of greenhouse gas emissions. Although conditions in a land fill are typically anaerobic, it is also possible to have aerobic 
conditions. The majority of current research articles report studies based on controlling mixtures and conditions to minimize greenhouse emissions.

Pier and Kelly [1997] indicate that as a result of it high degradable organic carbon content of wood wastes combined with a tendency for anaerobic onsite storage conditions, wood wastes are a potent potential source of methane production. They also indicate that the emissions from such wastes would be much higher if such stored wastes were put in soilcapped landfills. $\mathrm{CO}_{2}$ and methane emission rates were measured in terms of mass emitted per surface area of a sawdust pile. They found methane flux rates that were within, but at the low end of the range of landfill methane emission values, as reported in the literature.

Traditional landfills tend to be significant sources of greenhouse gases. If one assumes similar processes will occur for the wood as for the other organic materials in the landfill, then the disposal of wood chips in a landfill will result in significant releases of potent greenhouse gases - and thus from the viewpoint of the potential to generate greenhouse gas, burial in a traditional landfill will be a less desirable fate for the wood chips than the proposed incineration process.

Typical landfill gas composition includes $63.8 \% \mathrm{CH}_{4}, 33.6 \% \mathrm{CO}_{2}, 0.16 \% \mathrm{O}_{2}, 2.4 \%$ nitrogen $\left(\mathrm{N}_{2}\right), 0.05 \%$ hydrogen $\left(\mathrm{H}_{2}\right), 0.001 \%$ carbon monoxide $(\mathrm{CO}), 0.005 \%$ ethane $\left(\mathrm{C}_{2} \mathrm{H}_{6}\right), 0.018 \%$ ethane $\left(\mathrm{C}_{2} \mathrm{H}_{4}\right), 0.005 \%$ acetaldehyde $\left(\mathrm{C}_{2} \mathrm{H}_{5} \mathrm{O}\right), 0.002 \%$ propane $\left(\mathrm{C}_{3} \mathrm{H}_{8}\right), 0.003 \%$ butanes $\left(\mathrm{C}_{3} \mathrm{H}_{8}\right), 0.00005 \%$ helium $(\mathrm{He}),<0.05 \%$ higher alkanes, $0.009 \%$ unsaturated hydrocarbons, $0.00002 \%$ halogenated compounds, $0.00002 \%$ hydrogen sulphide $\left(\mathrm{H}_{2} \mathrm{~S}\right), \quad 0.00001 \%$ organosulphur compounds, $0.00001 \%$ alcohols, and $0.00005 \%$ other compounds [Al-Dabbas, 1998]. Although recent work by Launghi et al. and references therein suggested different percentages of the landfill gas composition in Europe, $\mathrm{CH}_{4}$ content is highest among landfill gas emission [Lunghi et al., 2004]. Based on the Italian report, $\mathrm{CH}_{4}$ accounts for $58.01 \%, \mathrm{CO}_{2}$, $41.38 \%, \mathrm{O}_{2}, 0.13 \%, \mathrm{~N}_{2} 0.48 \%$, and $\mathrm{H}_{2} \mathrm{O} 0.41 \%$.

Methane can be formed by various paths including biogenic (bacterial) methane formation, thermogenic formation, and incomplete combustion of biomass or fossil fuels. After formation of $\mathrm{CH}_{4}$, it can be modified by secondary processes. One of the most important processes is aerobic $\mathrm{CH}_{4}$ oxidation by methanotrophic bacteria, which occurs in many natural and anthropogenic environments producing $\mathrm{CH}_{4}$ under anaerobic conditions. Substantial aerobic methane oxidation has been found in various environments such as natural wetlands, rice paddies and landfill sites [Bergamaschi et al., 1998].

Emission of $\mathrm{CH}_{4}$ from landfills is causing increasing concerns in global climate change, because its warming potential is 20 times higher than that of $\mathrm{CO}_{2}$ in a time trajectory of 100 years [Kumar et al., 2004a; Kumer et al., 2004b]. Formation of organic compounds including degradable materials with high molecular weights is closely linked with emission of $\mathrm{CH}_{4}$ in landfills [Pan and Voulvoulis, 2007].

IPCC (2007) states that:

"Worldwide, the dominant methods of waste disposal are landfills and open dumps. Although these disposal methods often have lower first costs, they may contribute to serious local air and water pollution, and release high GWP landfill gas (LFG). LFG is generated when organic material decomposes anaerobically. It comprises approximately $50 \%-60 \%$ methane, $40 \%-45 \% \mathrm{CO}_{2}$ and the traces of non-methane volatile 
organics and halogenated organics. In 1995, US, landfill methane emissions of $64 \mathrm{MtC}_{\mathrm{eq}}$ slightly exceed its agricultural sector methane from livestock and manure.

Methane emission from landfills varies considerably depending on the waste characteristics (composition, density, particle size), moisture content, nutrients, microbes, temperature, and $\mathrm{pH}$ [El-Fadel, 1998]. Data from field studies conducted worldwide indicate that landfill methane production may range over six orders of magnitude (between $0.003-3000 \mathrm{~g} / \mathrm{m}^{2} /$ day) [Bogner et al., 1985]. Not all landfill methane is emitted into the air; some is stored in the landfill and part is oxidized to $\mathrm{CO}_{2}$. The IPCC theoretical approach for methane estimation has been complemented with more recent, site-specific models that take into account local conditions such as soil type, climate, and methane oxidation rates to calculate overall methane emissions [Bogner et al., 1998].

Laboratory experiments suggest that a fraction of the carbon in landfilled organic waste may be sequestered indefinitely in landfills depending upon local conditions. However, there are no plausible scenarios in which landfilling minimizes greenhouse gas emissions from waste management (italics added). For yard waste, greenhouse gas emissions are roughly comparable from landfilling and composting; for food waste, composting yields significantly lower emissions than landfilling. For paper waste, landfilling causes higher greenhouse gas emissions than either recycling or incineration with energy recovery [US EPA, 2000]."

The potential for the gases produced in landfills to be collected as a biomass source is being considered [McKendry, $2002 \mathrm{a} ; \mathrm{b} ; \mathrm{c}$ ] as a process that potentially could put the landfill greenhouse emissions on a par with the proposed heat plant.

\subsubsection{Open burning}

The disposal of the wood chips by open burning is considered. Fires produce gases and aerosols to the atmosphere such as $\mathrm{CO}_{2}, \mathrm{CO}$, nitrogen oxides $\left(\mathrm{NO}_{\mathrm{x}}\right)$, volatile and semivolatile organic compounds (VOC and SVOC), particulate matter (PM), $\mathrm{NH}_{3}$, sulfur dioxide $\left(\mathrm{SO}_{2}\right)$, and $\mathrm{CH}_{4}$ [Clinton et al., 2006].

The literature on biomass combustion encompasses biofuels (wood, crop waste, and dugcake) and forest fires (accidental, shifting, cultivation, and controlled burning). In a study based in India, forest fires were reported as only being a $7 \%$ portion of the $93 \%$ of total combustion sources from biomass consumption [Reddy and Venkataraman, 2002]. Greenhouse gas emission from biofuel burning is much less in comparison to emission from open vegetation fires [Ito and Penner, 2005].

Open burning produces a much more complex mix of gas emissions. Hays et al. examined fine particulate matter $\left(\mathrm{PM}_{2.5}\right)$ and gas phase emissions from open burning of six fine foliar fuels commonly found in fire-prone ecosystems in the U.S. [Hays et al., 2002]. They identified more than 100 individual organic compounds in the fine carbonaceous particulate matter using gas chromatography/mass spectrometry. The emission ranges by organic compound class are the following, n-alkane $0.1-2 \%$, ploycyclic aromatic hydrocarbon (PAH) $0.02-0.2 \%$, n-alkanoic acid 1-3\%) n-alkanedioic acid 0.06-0.3\%, n-alkenoic acid $0.3-3 \%$, resin acid $0.5-6 \%$, triterpenoid $0.2-0.5 \%$, methoxyphenol $0.5-3 \%$, and phytoseterol $0.2-0.6 \%$. 
Table 2 compares the relative emissions from the proposed heat plant and the alternative of open burning of the wood chips based on emission factors listed in US EPA guidance [US EPA, 2008].

\begin{tabular}{|l|l|l|l|}
\hline Combustion Scenario & Current Heat Plant & $\begin{array}{l}\text { Proposed } \\
\text { Heat Plant }\end{array}$ & $\begin{array}{l}\text { Equivalent Mass } \\
\text { of Wood }\end{array}$ \\
\hline Air Pollutant & $\begin{array}{l}\text { Existing } \\
\text { Emissions Using } \\
\text { Natural Gas Boilers }\end{array}$ & $\begin{array}{l}\text { Wood } \\
\text { Combustion }\end{array}$ & Open Burning \\
\hline Units & tons/yr & tons/yr & tons/yr \\
\hline Carbon Monoxide $(\mathrm{CO})$ & 1.69 & 3.58 & $\begin{array}{l}270 .(\mathrm{b}) \\
170-370(\mathrm{c})\end{array}$ \\
\hline Sulfur Dioxide $\left(\mathrm{SO}_{2}\right)$ & 0.012 & 0.5 & $\begin{array}{l}\text { Not } \\
\text { listed }\end{array}$ \\
\hline Nitrogen Oxide $\left(\mathrm{NO}_{\mathbf{x}}\right)$ & 3.3 & 4.3 & 7.7 (b) \\
\hline PM Total & 0.1 & 3.2 & $\begin{array}{l}32 .(\mathrm{b}) \\
7.6-32 .(\mathrm{c})\end{array}$ \\
\hline VOC (non methane) & 0.1 & 0.1 & $\begin{array}{l}45.8(\mathrm{~b}) \\
7.6-36 .(\mathrm{c})\end{array}$ \\
\hline Carbon Dioxide $\left(\mathrm{CO}_{2}\right)$ & 2340 & Net zero & $\begin{array}{l}\text { Net Zero } \\
\text { (Not Listed) }\end{array}$ \\
\hline Methane $\left(\mathrm{CH}_{4}\right)$ & $(\mathrm{a})$ & $(\mathrm{a})$ & $6.2-10.8(\mathrm{c})$ \\
\hline
\end{tabular}

(a) no value listed, expected to be negligible

(b) estimated based on Rocky Mountain wildfire forest burning emission factors (AP-42, Table 13.1-3)

(c) estimated based on forest wastes burning emission factors (AP-42, Table 2.5-5)

(d) can be a significant source depending on conditions in the landfill.

(e) can be a significant source depending on the composting conditions.

Table 2. Comparison of Emissions: Current Plant, Proposed Plant, and Open Burning

Mouillot et al. [2006] concluded that "The total amount of carbon emitted to the atmosphere from biomass burning is uncertain." Neither combustion efficiencies nor the extent of burned areas are known with precision [Ito and Penner, 2005; Kasischke and Penner, 2004].

The argument for increased use of biofuels instead of fossil fuels is based on considering $\mathrm{CO}_{2}$ from biomass burning as recyclable. An obvious question is whether the use of biofuels should be reduced as a strategy for reducing the total emissions of greenhouse gases. In fact, researchers predict that the effect of controls on biomass burning on climate change will be mildly effective in reducing $\mathrm{CO}_{2}$ emissions - leading to a prediction of a short-term warming followed by a longer-term global cooling [Jacobson, 2004]. Although the Kyoto Protocol did not consider biomass-burning controls as a means of reducing global warming, there is an argument that at least in the time-frame of the next decade this strategy has the potential of reducing global warming.

\subsection{Waste to energy facilities}

The emission rates from waste to energy combustion in the proposed biomass heat plant are likely to be similar to those from incineration as opposed to those discussed above for open burning, landfilling, and composting. 
ITCC [2007] states:

"Incineration is common in the industrialized regions of Europe, Japan and the northeastern USA where space limitations, high land costs, and political opposition to locating landfills in communities limit land disposal. In developing countries, low land and labor costs, the lack of high heat value materials such as paper and plastic in the waste stream, and the high capital cost of incinerators have discouraged waste combustion as an option.

Waste-to-energy (WTE) plants create heat and electricity from burning mixed solid waste. Because of high corrosion in the boilers, the steam temperature in WTE plants is less than 400 degrees Celsius. As a result, total system efficiency of WTE plants is only between 12\%-24\% [Faaj et al., 1998; US EPA, 1998; Swithenbank and Nasserzadeh, 1997].

Net greenhouse gas emissions from WTE facilities are usually low and comparable to those from biomass energy systems, because electricity and heat are generated largely from photosynthetically produced paper, yard waste, and organic garbage rather than from fossil fuels. Only the combustion of fossil fuel based waste such as plastics and synthetic fabrics contribute to net greenhouse gas releases, but recycling of these materials generally produces even lower emissions."

Based on a broader life-cycle perspective, Borjesson and Berglund [Borjesson and Berglund, 2006; Berglund and Borjesson, 2006] address the overall environmental impact when biogas systems are introduced to replace various conventional systems for energy generation, waste management and agricultural production. Their conclusion is that biogas systems normally also lead to indirect environmental improvements, which in some cases are considerable. They note that these indirect benefits (e.g. reduced nitrogen leaching, emissions of ammonia and methane) often exceed the direct environmental benefits achieved in situation when fossil fuels are to be replaced by biogas.

\section{Conclusions}

Conversion of the NREL heat plant will replace combustion of fossil fuels with a biomass fuel. The literature was found to support this action in terms of emissions of greenhouse gases.

Although the reduction of any of the major emission sources can be an effective strategy for slowing the increase in atmospheric greenhouse gases, the literature also strongly supports the replacement of fossil fuels with biomass fuels based on the concept of stopping the release of "new" carbon currently sequestered in fossil fuels.

When compared to open burning, the proposed conversion is desirable in terms of the emission of pollutants. The comparison in Table 2 based on EPA's AP-42 indicates the same mass wood chips by open burning would significantly increase the emissions of carbon monoxide, total particulate matter, and VOCs. The literature indicates only a factor of 2 increase in nitrogen oxide emissions.

When compared to disposal in a landfill, the evidence is also in favor of the proposed conversion. Disposal landfills have the advantage over the biomass heat plant in that the landfill will generally not be a significant source of particulate matter. On the other hand, wood chips in a landfill with actively decomposing materials would produce a more potent 
mixture of greenhouse gasses (i.e. increased levels of methane and ammonia). The potential for the gases produced in landfills to be collected as a biomass source is considered as a process that potentially in the future could put the landfill greenhouse emissions on a par with the proposed heat plant [McKendry, 2002a]. IPCC [2007] indicates that there are no plausible scenarios in which landfilling minimizes greenhouse gas emissions from waste management.

When compared to composting, the proposed conversion is desirable in terms of the emission of pollutants. Although the literature is full of studies to make the emissions from composting more "greenhouse gas friendly," the current status is that a composting technology for organic material such as wood chips only minimizes the emissions of greenhouse gases. The high temperature combustion process used in the proposed biomass heat plant mainly produces $\mathrm{CO}_{2}$ while nearly eliminating the emissions of the other more potent greenhouse gases.

Thus the concept of reducing the potential global warming impacts from burning of biomass is consistent with the proposed conversion of the heat plant. As seen in this review, in addition to using a recycled source of carbon, the high temperature combustion of the wood chips results in a net decrease in the climate-change potency of the greenhouse gas emissions compared to current use/destruction of wood chips in composting and open burning.

\section{References}

Al-Dabbas, M. A. F. (1998), Reduction of methane emissions and utilization of municipal waste for energy in Amman, Renewable Energy, 14(1-4), 427-434.

Bergamaschi, P., C. Lubina, R. Konigstedt, et al. (1998), Stable isotopic signatures (delta C13, delta D) of methane from European landfill sites, Journal of Geophysical ResearchAtmospheres, 103(D7), 8251-8265.

Berglund, M., and P. Borjesson (2006), Assessment of energy performance in the life-cycle of biogas production, Biomass \& Bioenergy, 30(3), 254-266.

Bogner, J., K. Spokas, E. Burton, et al. (1995), LANDFILLS AS ATMOSPHERIC METHANE SOURCES AND SINKS, Chemosphere, 31(9), 4119-4130.

Bogner, J. E., K. A. Spokas, and E. A. Burton (1999), Temporal variations in greenhouse gas emissions at a midlatitude landfill, Journal of Environmental Quality, 28(1), 278-288.

Borgwardt, R. H. (1997), Biomass and natural gas as co-feedstocks for production of fuel for fuel-cell vehicles, Biomass \& Bioenergy, 12(5), 333-345.

Borjesson, P., and M. Berglund (2006), Environmental systems analysis of biogas systems Part 1: Fuel-cycle emissions, Biomass \& Bioenergy, 30(5), 469-485.

Clinton, N. E., P. Gong, and K. Scott (2006), Quantification of pollutants emitted from very large wildland fires in Southern California, USA, Atmospheric Environment, 40(20), 3686-3695.

Dennis, A., M. Fraser, S. Anderson, et al. (2002), Air pollutant emissions associated with forest, grassland, and agricultural burning in Texas, Atmospheric Environment, 36(23), 3779-3792.

Faij, A. P. C. (2006). "Bio-energy in Europe: changing technology choices." Energy Policy, 34(3): 322-342.

Hays, M. D., C. D. Geron, K. J. Linna, et al. (2002), Speciation of gas-phase and fine particle emissions from burning of foliar fuels, Environmental Science \& Technology, 36(11), 22812295. 
Hays, M. D., P. M. Fine, C. D. Geron, et al. (2005), Open burning of agricultural biomass: Physical and chemical properties of particle-phase emissions, Atmospheric Environment, 39(36), 6747-6764.

IPCC, 2007. Climate Change 2007: The Physical Science Basis: Summary for Policymakers. Contribution of Working Group I to the Fourth Assessment Report of the Intergovernmental Panel on Climate Change. Available at http:// www.ipcc.ch, last accessed May 4, 2007.

IPCC, 2001. Climate Change 2001: Mitigation. Contribution of Working Group III to the Third Assessment Report of the Intergovernmental Panel on Climate Change. Available at http://www.ipcc.ch, last accessed May 4, 2007.

Ito, A, and J. E. Penner (2005), Historical emissions of carbonaceous aerosols from biomass and fossil fuel burning for the period 1870-2000, Global Biogeochemical Cycles, 19(2).

Ito, A., and J. E. Penner (2004), Global estimates of biomass burning emissions based on satellite imagery for the year 2000, Journal of Geophysical Research-Atmospheres, 109(D14).

Jacobson, M. Z. (2004), The short-term cooling but long-term global warming due to biomass burning, J. Clim., 17(15): 2909-2926.

Kasischke, E. S., and J. E. Penner (2004), Improving global estimates of atmospheric emissions from biomass burning, Journal of Geophysical Research-Atmospheres, 109(D14).

Khalil, M. A. K., and R. A. Rasmussen (2003), Tracers of wood smoke, Atmospheric Environment, 37(9-10), 1211-1222.

Kumar, S., S. A. Gaikwad, A. V. Shekdar, et al. (2004a), Estimation method for national methane emission from solid waste landfills, Atmospheric Environment, 38(21), 3481-3487.

Kumar, S., A. N. Mondal, S. A. Gaikwad, et al. (2004b), Qualitative assessment of methane emission inventory from municipal solid waste disposal sites: a case study, Atmospheric Environment, 38(29), 4921-4929.

Lang, D. J., C. R. Binder, R. W. Scholz, et al. (2006), Impact factors and regulatory mechanisms for material flow management: Integrating stakeholder and scientific perspectives - The case of bio-waste delivery, Resources Conservation and Recycling, $47(2), 101-132$.

Liebig, M. A., J. A. Morgan, J. D. Reeder, et al. (2005), Greenhouse gas contributions and mitigation potential of agricultural practices in northwestern USA and western Canada, Soil \& Tillage Research, 83(1), 25-52.

Ligon, J. M., D. S. Hill, P. Hammer, et al. (1999), Natural products with antimicrobial activity from Pseudomonas biocontrol bacteria, in Pesticide Chemistry and Bioscience: The Food-Environment Challenge, edited by G. T. Brooks and T. R. Roberts, pp. 179-189.

Lunghi, P., R. Bove, and U. Desideri (2004), Life-cycle-assessment of fuel-cells-based landfillgas energy conversion technologies, Journal of Power Sources, 131(1-2), 120-126.

McKendry, P. (2002a), Energy production from biomass (part 1): overview of biomass, Bioresource Technology, 83(1): 37-46.

McKendry, P. (2002b), Energy production from biomass (part 2): conversion technologies, Bioresource Technology, 83(1): 47-54.

McKendry, P. (2002c.) Energy production from biomass (part 3): gasification technologies, Bioresource Technology, 83(1): 55-63.

Mouillot, F., A. Narasimha, Y. Balkanski, J.F. Lamarque, and C.B. Field (2006), Global carbon emissions from biomass burning in the 20th century, Geophysical Research Letters, 33(1).

Oros, D. R., and B. R. T. Simoneit (2001), Identification and emission factors of molecular tracers in organic aerosols from biomass burning Part 1. Temperate climate conifers, Applied Geochemistry, 16(13), 1513-1544. 
Pan, J. L., and N. Voulvoulis (2007), The role of mechanical and biological treatment in reducing methane emissions from landfill disposal of municipal solid waste in the United Kingdom, Journal of the Air \& Waste Management Association, 57(2), 155-163.

Pier, P. A., and J. M. Kelly (1997), Measured and estimated methane and carbon dioxide emissions from sawdust waste in the Tennessee Valley under alternative management strategies, Bioresource Technology, 61(3), 213-220.

Pronobis, M. (2006), The influence of biomass co-combustion on boiler fouling and efficiency, Fuel, 85(4), 474-480.

Reddy, MS, and C Venkataraman (2002), Inventory of aerosol and sulphur dioxide emissions from India. Part II - biomass combustion, Atmos. Environ., 36(4): 699-712.

Reiner, T., D. Sprung, C. Jost, et al. (2001), Chemical characterization of pollution layers over the tropical Indian Ocean: Signatures of emissions from biomass and fossil fuel burning, Journal of Geophysical Research-Atmospheres, 106(D22), 28497-28510.

Schmid, O., P. Artaxo, W. P. Arnott, et al. (2006), Spectral light absorption by ambient aerosols influenced by biomass burning in the Amazon Basin. I: Comparison and field calibration of absorption measurement techniques, Atmospheric Chemistry and Physics, 6, 3443-3462.

Swithenbank, J., V. Nasserzadeh, R. Taib, et al. (1997), Incineration of wastes in novel highefficiency tumbling and rotating, fluidized bed incinerator, Journal of Environmental Engineering-Asce, 123(10), 1047-1052.

Suzuki, T, Y Ikumi, S Okamoto, I Watanabe, N Fujitake, and H Otsuka. (2004), Aerobic composting of chips from clear-cut trees with various co-materials, Bioresource Technology, 95(2): 121-128.

Tilman, D., J. Hill, and C. Lehman (2006), Carbon-negative biofuels from low-input highdiversity grassland biomass, Science, 314(5805), 1598-1600.

Turn, S. Q., B. M. Jenkins, J. C. Chow, et al. (1997), Elemental characterization of particulate matter emitted from biomass burning: Wind tunnel derived source profiles for herbaceous and wood fuels, Journal of Geophysical Research-Atmospheres, 102(D3), 3683-3699.

Wiedinmyer, C., B. Quayle, C. Geron, et al. (2006a), Estimating emissions from fires in North America for air quality modeling, Atmospheric Environment, 40(19), 3419-3432.

Wiedinmyer, C., X. X. Tie, A. Guenther, et al. (2006b), Future changes in biogenic isoprene emissions: How might they affect regional and global atmospheric chemistry?, Earth Interactions, 10.

Winiwarter, W., and K. Rypdal (2001), Assessing the uncertainty associated, with national greenhouse gas emission inventories: a case study for Austria, Atmospheric Environment, 35(32), 5425-5440.

US EPA (1998), Compilation of Air Pollutant Emission Factors, AP-42, 5th Edition, Volume 1: Stationary Point and Area Sources Chapter 2: Solid Waste Disposal, Section 2.4, U.S. EPA Supplement E, November 1998. p. 2.4 - 4.

US EPA (2000), Municipal solid waste in the United States: 2000 Facts and Figures. 2000 Update, EPA530-R-02-001.

USEPA (2007), Technology transfer network clearinghouse for inventories \& emissions factors, edited.

USEPA (2008), Climate leaders: Greenhouse gas inventory protocol core module guidance Direct emissions from stationary combustions sources, EPA430-K-08-003, www.epa.gov/climateleaders, May 2008. 


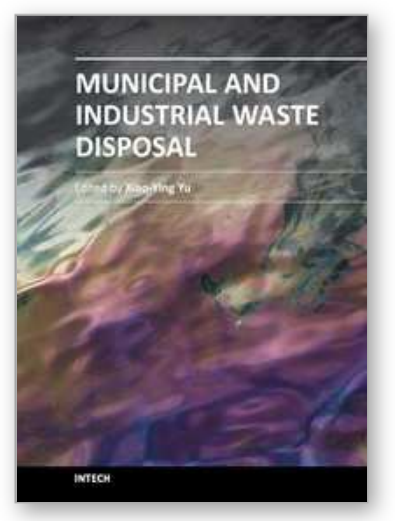

\author{
Municipal and Industrial Waste Disposal \\ Edited by Dr. Xiao-Ying Yu
}

ISBN 978-953-51-0501-5

Hard cover, 242 pages

Publisher InTech

Published online 11, April, 2012

Published in print edition April, 2012

This book reports research findings on several interesting topics in waste disposal including geophysical methods in site studies, municipal solid waste disposal site investigation, integrated study of contamination flow path at a waste disposal site, nuclear waste disposal, case studies of disposal of municipal wastes in different environments and locations, and emissions related to waste disposal.

\title{
How to reference
}

In order to correctly reference this scholarly work, feel free to copy and paste the following:

James G. Droppo and Xiao-Ying Yu (2012). Evaluation of Replacing Natural Gas Heat Plant with a Biomass Heat Plant - A Technical Review of Greenhouse Gas Emission Trade-Offs, Municipal and Industrial Waste Disposal, Dr. Xiao-Ying Yu (Ed.), ISBN: 978-953-51-0501-5, InTech, Available from:

http://www.intechopen.com/books/municipal-and-industrial-waste-disposal/evaluation-of-replacing-natural-gasheat-plant-with-a-biomass-heat-plant

\section{INTECH}

open science | open minds

\author{
InTech Europe \\ University Campus STeP Ri \\ Slavka Krautzeka 83/A \\ 51000 Rijeka, Croatia \\ Phone: +385 (51) 770447 \\ Fax: +385 (51) 686166 \\ www.intechopen.com
}

\author{
InTech China \\ Unit 405, Office Block, Hotel Equatorial Shanghai \\ No.65, Yan An Road (West), Shanghai, 200040, China \\ 中国上海市延安西路65号上海国际贵都大饭店办公楼 405 单元 \\ Phone: +86-21-62489820 \\ Fax: $+86-21-62489821$
}


(C) 2012 The Author(s). Licensee IntechOpen. This is an open access article distributed under the terms of the Creative Commons Attribution 3.0 License, which permits unrestricted use, distribution, and reproduction in any medium, provided the original work is properly cited. 